\title{
Molecular and Phylogenetic Analysis of Hemaglutinin Gene of Avian Influenza a Viruses Subtype H5N1 Isolate from Quail
}

\author{
Teuku Zahrial Helmi ${ }^{*}$, Wayan Tunas Artama ${ }^{2}$, Aris Haryanto ${ }^{2}$, Rumi Sahara \\ Zamzami $^{3}$ \\ ${ }^{1}$ Laboratory of Biochemistry, Faculty of Veterinary Medicine, Universitas Syiah Kuala, Banda Aceh \\ ${ }^{2}$ Laboratory of Biochemistry, Faculty of Veterinary Medicine, Universitas Gadjah Mada, Yogyakarta \\ ${ }^{3}$ Laboratory of Clinic, Faculty of Veterinary Medicine, Universitas Syiah Kuala, Banda Aceh \\ *Corresponding author. Email:zahrial_fkh@unsyiah.ac.id
}

\begin{abstract}
Based on the level of infection, the Avian Influenza (AI) virus can be grouped into 2 levels of infection, namely highly pathogenic avian influenza (HPAI) and low pathogenic avian influenza (LPAI). The pathogenicity of AI viruses was determined by the amino acid sequence at the site of the hemaglutinin glycoprotein (HA) cleavage and the distribution of the host cell protease. Most of the low pathogenic AI viruses have monobasic amino acids in the cleavage site (PQKETR*GLF), whereas in highly pathogenic strains they have polybasic cleavage (PQGERRRKKR*GLF). Polybase cleavage sites that are identical to the polybase cleavage sites of HPAI were found in all H5N1 virus clades of Asia, Europe, and African countries. The results revealed that all AI virus isolates studied showed a repetition pattern of amino acids Arginine (R) and Lysine (K) in the cleavage site (cs). The alignment of the HA gene nucleotide sequences of AI virus isolates from quail with Genebank isolates that have been carried out shows that the genetic distance value between AI virus isolates subtype H5 originating from quail from Aceh province and comparison isolates from genebank is between $0.01-8.1 \%$, with the homology ranges from $99.9 \%$ to $91.9 \%$. Phylogenic tree analysis showed that all analyzed viruses generally formed three major clades, namely the Indonesian and Southeast Asian clades (clade 2), the Asian clade (clade 1), and clade 0 (A/goose/Guangdong/96). From this study it can be concluded that all AI virus isolates that developed in Aceh province were included in the highly pathogenic group, and were still included in clade 2.1.3.
\end{abstract}

Keywords: virus influenza, puyuh, highly pathogenic, low pathogenic, cleavage site

\section{INTRODUCTION}

Avian Influenza (AI) is carried by influenza virus type A, sub-type H5N1, which can cause influenza disease in poultry and domestic animals such as horses, pigs and also humans [1][2]. Influenza virus particles are enveloped, segmented and have a negative single strain of ribonucleid acid (ssRNA). AI viruses have bulges (spikes) that are used to attach to specific receptors on their host cells when infecting the cells. AI viruses have 2 types of spikes, namely those containing hemagglutinin (HA) and those containing neuraminidase (NA), which are located in the outer portion of the virion [3].

Based on the level of infection, AI virus can be catagorized into 2 levels of infection i.e. highly pathogenic avian influenza (HPAI) and low pathogenic avian influenza (LPAI). The pathogenicity of AI viruses is determined by amino acid sequences in the cleavage site of hemagglutinin glycoprotein sites and the distribution of host cell proteases [4]. Each HA monomer is initially a precursor of a single polypeptide (HA0) which is cut into 2 subunits, HA1 and HA2. Proteolytic HA genes in the cleavage site are fundamental for viral infectivity. The cleavage site area of HA depends on the presence of basic amino acids (arginine: R) [5]. Most non-virulent or low pathogenic AI viruses have monobasic amino acids in the cleavage site $(\mathrm{PQKETR} * \mathrm{GLF})$ area, whereas highly pathogenic strains have polybasic cleavage (PQGERRRKKR*GLF). Polyibasic cleavage sites which are identical to HPAI cleavage sites are found in all other $\mathrm{H} 5 \mathrm{~N} 1$ clade 2 viruses in Asian, European and African countries [6]. 
Since the beginning of the outbreak in 2003, the HPAI H5N1 subtype virus in Indonesia is included in clade 2.1 which is further divided into 3 subclades in the following order: 2.1.1, 2.1.2, and 2.1.3. Subclade 2.1.2 was largely isolated from birds infected with HPAI during the outbreak between 2004 and 2007. Subclade 2.1.2 consists of viruses that infect poultry and humans, which were isolated mainly from Sumatra in 2004-2007. Subclade 2.1.3 consists of a series of viruses isolated from poultry and humans since 2004. Subclade 2.1.3 has become the most dominant in Indonesia, while subclades 2.1.1 and 2.1.2 have decreased since 2005. Subclade 2.1.3 has spread and become endemic in many provinces in Indonesia. The results of the evolution of the subclade 2.1.3 have formed the new subclade, but are still included in the subclade 2.1.3 [7, 8].

Based on the background, this study was conducted to determine the pattern of amino acids in the cleavage site and phylogenetic regions of the AI H5N1 virus type that developed in Indonesia, especially in the province of Aceh in 2015.

\section{MATERIALS AND METHODS}

The samples of this study used four virus isolates; $3 \mathrm{H} 5 \mathrm{~N} 1$ isolates of quails from Aceh and $1 \mathrm{H} 5 \mathrm{~N} 1$ virus isolates Yogyakarta.

\subsection{RNA Extraction}

The isolation of RNA of the viruses from chorioalantoic fluid was carried out using a PurelinkTM micro-to-Midi total RNA purifacation system. Viral RNA isolation technique is carried out in accordance with standard procedures issued by the kit manufacturer (Invitrogen).

\subsection{Amplification of H5 Gene by RT-PCR}

Amplification of $\quad \mathrm{H} 5$ gene was carried out using primers designed in reference with nucleotide genome sequence of the avian influenza virus strain from Gen Bank with an access code (HQ677023.1). A pair forward primers and reverse primers are designed using a blast primer from NCBI.

Amplification of H5 gene employed one step RTPCR method. The steps were conducted to produce a master mix with a volume of $22.5 \mu \mathrm{l}$ for one sample. In the beginning, A total of $1 \mathrm{x}$ buffer mix reaction with a volume of $12.5 \mu \mathrm{l}$ was inserted into the tube and was added with $1 \mu \mathrm{l}$ forward primer and 1 reverse primer specific to the H5 gene with a concentration of 10 $\mathrm{pmol} / \mu \mathrm{l}$, respectively. Afterwards, the solution was added with $6.5 \mu \mathrm{l} \mathrm{dH} 2 \mathrm{O}$ and $1 \mu \mathrm{l}$ of the enzyme Superscript $^{\mathrm{TM}}$ III One-Step RT-PCR Taq Polymerase.
Finally, the master mix was added with $3 \mu 1$ templates so that the total reaction volume for one sample was $25 \mu$ l. The PCR reaction mixture consisting of a master mix and a template is ready for amplification.

\subsection{Sequencing of Nucleotide Sequences}

One-step RT-PCR products were sequenced from the H5 gene and the samples were sent in the form of cDNA. DNA sequencing is carried out enzymatically (Chaín termination reaction), with dye terminator cycle sequencing. Before sequencing, the PCR product must be purified. Purification is conducted to clean the PCR product from the remaining buffer and other reaction components.

\subsection{Analysis of Sequencing Results Data}

Sequencing results in the form of chromatograms were analyzed using the MEGA 6.06 software program.

\section{RESULTS AND DISCUSSION}

\subsection{Sequencing of H5 Genes of AI Virus Quail Isolates}

The results of RT-PCR amplification of H5 gene in 4 samples of AI virus showed the magnitude of the amplicon at position 1,725 bp (Figure 1). Subsequently, the sequencing processes were implemented to the isolates.

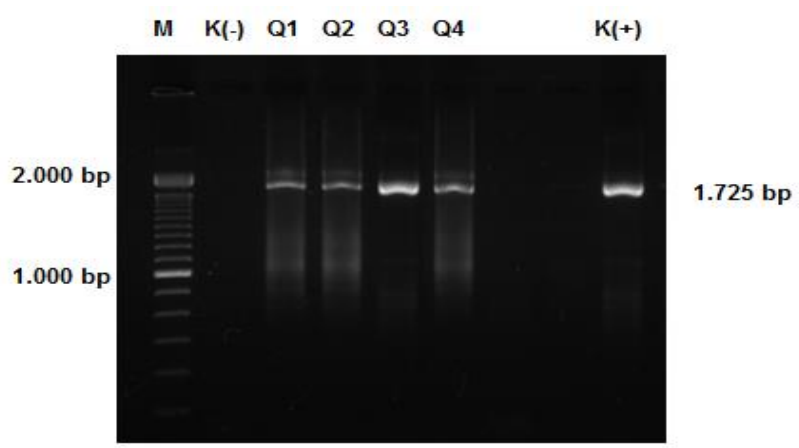

Figure 1 Electrophoresis results of RT-PCR H5 gene fragment at 1,725 bp position from 4 research samples which will be sequenced. M (marker): $100 \mathrm{bp}$; K (-): negative control; Q1, Q2, and Q4: samples from quails from Aceh; Q3: Quail sample from Yogyakarta; K (+): positive control.

Sequencing results were then analyzed using Mega 6.06 software, and alignment using Clustal W program. Sequencing analysis includes molecular identification of AI virus pathogenicity markers through Cleavage Site 
Region (CSR) analysis, genetic distance analysis, and phylogenetic tree analysis.

\subsection{Cleavage Site Region (CSR) Analysis}

Analysis of multiple alignment of Clustal W program from MEGA 6.0 software towards the alignment of fulllength amino acids of HA AI virus quail isolates obtained 558 amino acids, which numbering follows the H5 numbering system [4]. All AI virus isolates examined showed the repetition of Arginine (R) and Lysine (K) amino acids in the cleavage site (cs) area.

The results of the amino acid sequence alignment in the cleavage site area among AI virus isolates studied with comparative isolates from Genebank used in this study as a whole can be read in Table 1 .

Table 1. Multiple amino acid alignments upstream -11 to downstream +11 in the CSR (//) and Fusion site area

\begin{tabular}{|c|c|}
\hline Isolates Name & $\begin{array}{c}\text { The Order of Amino Acid in } \\
\text { the Cleavage Site Area }\end{array}$ \\
\hline \#A/Goose/Guangdong/1/96 & TPQRERRRKKR//GLFGAIAGF \\
\hline \#A/Quail/Aceh/ŽH-2/2013_(H5) & 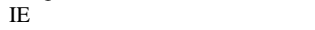 \\
\hline \#A/Quail/Aceh/ZH-3/2013_(H5) & S....S.....//........... \\
\hline \#A/Quail/Aceh/ZH-5/2013_(H5) & S....S.....///.......... \\
\hline \#A/chicken/Riau/UT531/2010 & S....S.....///.......... \\
\hline \#A/Chicken/Indo/GKidul/1631-33/2006 & S....S.....//.......... \\
\hline \#A/Chicken/Indo/Kulon/1631-47/2006 & 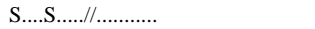 \\
\hline \#A/chicken/Bantul/BBVW/678.443/2007 & S....S.....///.......... \\
\hline \#A/chicken/Sukoharjo/BBVW-1148- & S....S.....//.......... \\
\hline 07/2011 & S....S.....///.......... \\
\hline \#A/tree_sparrow/Indonesia/D10013/2010 & S....S.....//.......... \\
\hline \#A/chicken/SouthKalimantan/UT521/2010 & 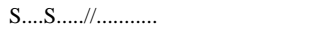 \\
\hline \#A/Chicken/Medan/BBPV1-571/2005 & S...........//_.......... \\
\hline \#A/Chicken/Pidie/BPPV1/2005 & S..........//........... \\
\hline \#A/Chicken/Langkat/BBPV1/576/2005 & S...........//_.......... \\
\hline \#A/Quail/Yogyakarta/ZH-8/2014_(H5) & S.........--//........... \\
\hline \#A/duck/Sukoharjo/BBVW/1428.9/2012 & S.........--//............ \\
\hline \#A/duck/WestSulawesi_Polman/1018/2012 & S.........--//........... \\
\hline \#A/quail/Vietnam/CVVI-50/2014 & S........--//............ \\
\hline \#A/Quail/Jakarta/JU1/2006 & S.........--//........... \\
\hline \#A/quail/Korea/GC395/2011 & S........--///........... \\
\hline \#A/duck/Sleman/BBVW/1003-34368/2007 & S.........///. \\
\hline
\end{tabular}

Note: the amino acid position of the upstream position (-11) is calculated from the sign (//) towards the front, while the downstream position $(+11)$ towards the back, the yellow color is the isolate under study, and the sign (-) indicates that the amino acid is experiencing deletion.

The results of the alignment analysis of nucleotide and amino acid sequences on AI virus isolates from quail origin Yogyakarta Special Region Province also showed mutations in the cleavage site area. Mutations at the nucleotide level were observed in the upstream positions -1 and -2 , where in this position there was deletion of 2 nucleotide bases (2nd and 3rd bases) in the upstream -2, and deletion of the first base, and substitution of adenine (A) to become guanine $(\mathrm{G})$ on the 3rd base at upstream 1. Changes in the arrangement of the nucleotides at the upstream positions -1 and -2 , causing deletion of 2 amino acids at these positions. This amino acid motif is in accordance with the research conducted by Srihanto (2014), where the AI virus from Lampung which was isolated between 2012 to 2013

from infected waterfowl, in the cleveage site area is composed of amino acids with the QRERRRKG pattern [9].

The amino acid cleavage site clade PQRERRRKR in Indonesia has the same pattern as clade 2.3.2 in cases of mass death of wild birds in Gengahai Lake, Qinghai Province, China in May-June 2009. This polybasic pattern shows clade 2.3.2 in Indonesia and China is H5N1. HPAI strains [8]. The amino acid composition at the isolate cleavage site was identical to the isolates from Vietnam $[10,11]$.

\subsection{Analysis of the Genetic Distance of AI Viruses}

The results of the alignment of HA nucleotide genes of AI virus isolates from quails and isolates that already exist in genebank showed that the genetic distance between AI virus H5 subtype isolates from Aceh with comparative isolates from genebank is between 0.01 $8.1 \%$, with homology between $99.9 \%-91.9 \%$. Genetic distance between AI isolates of H5 subtype from quails from Aceh was also observed; ranging between $0.0 \%$ $0.1 \%$, with homology between $100 \%-99.9 \%$. Comparison of full length genetic distance for HA genes between H5N1 subtype AI virus isolates from Quail from Aceh Province (Blue), and H5N1 subtype AI virus isolates obtained from Genebank is presented in Table 2.

According to Lee and Saif, changes in nucleotides and amino acids will cause mutations in the AI virus [1]. In each year, it is known that the mean changes of nucleotides in AI viruses are 7.8 and 4.9 amino acids per 1000 nucleotides in the HA gene [12]. Lee and Saif (2009) also stated that the high rate of changes / mutations will cause an increase in genetic drift caused by nucleotide changes in the HA1 unit [1]. The changes occur are due to evolutionary pressure as a viral response to the immune activity of the host [13].

\subsection{Phylogenetic Analysis}

Phylogenetic analysis of 1,678 nucleotide bases of $\mathrm{HA}$ virus AI subtype $\mathrm{H} 5$ quail isolates as the result of this study along with AI subtype H5N1 Indonesia and other comparative isolates from genebank are shown in Figure 2. Construction of phylogenetic trees was conducted using MEGA 6.0, Neighbor-Joining method with Kimura 2-parameter model and Bootstrapped 1000 repetitions.

Phylogenic tree analysis in Figure 2. showed that all viruses already studied, respectively, from three large clades: Indonesia and Southeast Asia (clade 2), Asian clade (clade 1) and clade 0 (A/goose/Guangdong/96). Virus clade 2, is further divided into subclades 2.1.1, 
2.1.2, and 2.1.3, which are AI virus isolates from poultry and humans circulating in Indonesia [14], as well as subclade 2.3.2 AI virus subtype H5N1 which is a new subclade in Indonesia [8]. Based on the study, the result indicated that the avian influenza outbreak which is still occurring in Aceh Province is caused by the same avian influenza virus subtype (Influenza A subtype H5) with the outbreak in 2004 to 2008 [15, 16].

Avian Influenza Virus (VAI) subtype H5N1 from various countries, phylogenetically separated into 2 clades. Clade 1 is a virus isolated in poultry and humans in Cambodia, Thailand, Vietnam, Laos, South Korea and Japan in 2003-2004. Clade 2 is divided into 3 subclades. Subclade 1 is a virus from Indonesia in 2004-2006, and a Hong Kong isolate from 2003. Subclade 2 is a virus isolate from Russia, Turkey and the Middle East from 2005 to 2006. Subclade 3 is an isolate from Laos, Thailand, Cambodia, and Vietnam in 2005 -2006 [17].

Tabel 2. Genetic Distance of Isolates of AI virus subtype H5 from Quail from Aceh with comparative isolates from genebank

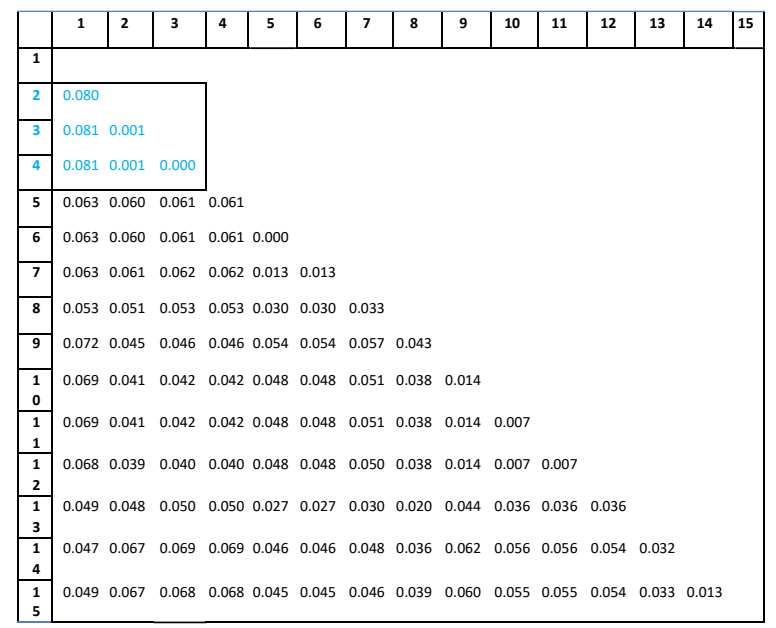

Isolate information:

\begin{tabular}{|c|c|}
\hline A/Goose/Guangdong/1/96(H5N1) & 9 A/chicken/Sleman/BBVW-1908-12/2012(H5N1) \\
\hline 2 A/Quail/Aceh/ZH-2/2013_H5) & $10 \mathrm{~A} / q u a i / B$ litar/BBVW/790.05/2011(H5N1) \\
\hline 3 A/Quail/Aceh/ZH-3/2013_(H5) & $11 \mathrm{~A} /$ chicken/Sukoharjo/BBVW-1148-07/2011(H5N1) \\
\hline 4 A/Quail/Aceh/ZH-5/2013_(H5) & $12 \mathrm{~A} /$ /tree_sparrow/Indonesia/D10013/2010(H5N1) \\
\hline 5 A/chicken/Riau/UT531/2010(H5N1) & 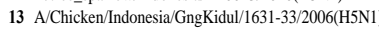 \\
\hline A/chicken/Central/Java/UT561/2010(H5N1) & $14 \mathrm{~A} /$ Chicken/GunungKidul/BBVW/2006(H5N1) \\
\hline 7 A/chicken/SouthKalimantan/UT521/2010(H5N1) & $15 \mathrm{~A} /$ Chicken/Indonesia/Kulon/1631-47/2006(H5N1) \\
\hline
\end{tabular}

Based on the geographic location of Indonesia, the spread of the AI virus is grouped into 3 groups, namely group A, B, and C. Group A is virus which spread in areas of Java, West Timor, and Sulawesi. Group B covers the regions of Java, Bali, Flores, and West Timor, while group C viruses represent viruses from Java, Sumatra and Bangka [7].

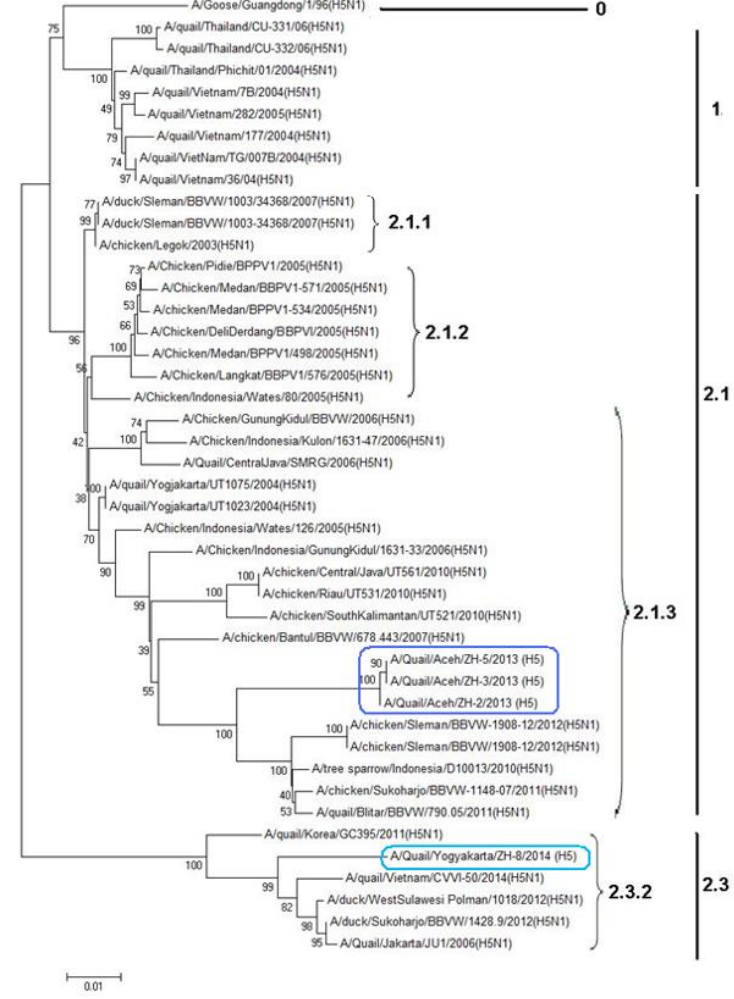

Figure 2 Phylogenetic analysis of HA H5N1 AI virus Quail isolates from Aceh paired with other avian influenza viruses from The Genebank

From phylogenetic analysis of the AI virus subtype H5 origin of Aceh, it is known that the virus isolates included into the sub-clade 2.1.3 is a different group of subtypes H5 AI virus coming from Aceh and Northern Sumatra in isolation in 2005 which is belong to the subclade 2.1.2. Based on the geographical distribution of the subtypes H5 AI virus isolates quail origin of Aceh province in this study is included into the AI virus isolates of group $\mathrm{C}$ which still have a relationship and adjacency with the Java AI virus group.

\section{CONCLUSION}

From this study it can be concluded that all of AI virus isolates that developed in Aceh Province are included in the highly pathogenic group. The amino acid pattern of the virus at the cleavage site area is PQRESRRKKR// GLFGAIAGFIE, and it still included in clade 2.1.3.

\section{AUTHORS' CONTRIBUTIONS}

This research has been designed by $\mathrm{TZH}$, and carried out by TZH and AH. The manuscript has been written by TZH, revised by WTA, translated and edited by RSZ. 


\section{ACKNOWLEDGMENT}

The authors would like to thank the Head of Balai Besar Veteriner (BBVet) Wates in Yogyakarta, the Ministry of Agriculture of The Republic of Indonesia for supporting this research. Authors also wish to thank to the Directorate General of Higer Education, Ministry of Education and Culture of The Republic of Indonesia who has funded the 2014 Fiscal Year Doctoral Dissertation Research Grant Project in number 076/UN11.2/PL/SP3/2014.

\section{REFERENCES}

[1] C.W. Lee, Y.M. Saif, Avian influenza virus. Comp. Immunol. Microb. 32(4) (2009) 301-310.

[2] W. M. Boyce, C. Sandrock, C. Kreuder-Johnson, T. Kelly, C. Cardona, Avian influenza viruses in wild birds: a moving target. Comp. Immunol. Microb. 32(4) (2009) 275-286.

[3] T. Horimoto, Y. Kawaoka, Pandemic threat posed by avian influenza A viruses. Clin. Microbiol. Rev. 14(1) (2001) 129-149.

[4] Y. Suzuki, The highly pathogenic avian influenza H5N1-initial molecular signals for the next influenza pandemic. Chang. Gung. Med. J. 32(3) (2009) 258-263.

[5] A.L. Suguitan, Y. Matsuoka, Y.F. Lau, C.P. Santos, L. Vogel, L.I. Cheng, M. Orandle, K. Subbarao, The multibasic cleavage site of the hemagglutinin of highly pathogenic A/Vietnam/1203/2004 (H5N1) avian influenza virus acts as a virulence factor in a host-specific manner in mammals. J. Virol. 86(5) (2012) 2706-2714.

[6] M.F. Ducatez, C. M. Olinger, A.A. Owoade, S. De Landtsheer, W. Ammerlaan, H.G.M. Niesters, A.D.M.E. Osterhaus, R.A.M. Fouchier, C.P. Muller, Avian flu: multiple introductions of $\mathrm{H} 5 \mathrm{~N} 1$ in Nigeria. Nature, 442(7098) (2006) 37-37.

[7] R. Takano, C.A. Nidom, M. Kiso, Y, Muramoto, S. Yamada, Y. Sakai-Tagawa, C. Macken,Y. Kawaoka, Phylogenetic characterization of H5N1 avian influenza viruses isolated in Indonesia from 2003-2007. Virol, 390(1) (2009) 13-21.

[8] E. Andesfha, N.K. Ramlah, E.R. Djusa,H Mucharini, Identifikasi molekuler dinamika genetik virus avian influenza subtipe H5N1 clade 2.1. 3 dan 2.3. 2. Buletin Pengujian Mutu Obat Hewan, 20 (2013) 34-45.

[9] E.A. Srihanto, Kajian Molekuler Patogenisitas Virus Avian Influenza Isolat Lampung 2004 - 2013,
Buletin Laboratorium Veteriner. 31(01) (2014) 0104.

[10] Serological and molecular analysis of avian influenza virus subtype H5 isolated from Aceh province in Indonesia, Int. J. Virol. 13 (2017) 62-67.

[11] WHO. Emergencies preparedness, response; Avian influenza - new areas with infection in birds, 2005. Online: http://www.who.int/csr/don/ 2005_10_13/en/. (Accessed: December $25^{\text {th }} 2020$ ).

[12] E.A. Srihanto, Kajian Molekuler Patogenisitas Virus Avian Influenza Isolat Lampung 2004 - 2013, Buletin Laboratorium Veteriner. 31(01) (2014) 0104.

[13] J. Pfeiffer, M. Pantin-Jackwood, T.L. To, T. Nguyen, D.L. Suarez, Phylogenetic and biological characterization of highly pathogenic $\mathrm{H} 5 \mathrm{~N} 1$ avian influenza viruses (Vietnam 2005) in chickens and ducks. J. Virus. Res., 142(1) (2009) 108-120.

[14] H. Wibawa, W.B. Prijono., N.L.P.I Dharmayanti., S.H. Irianingsih., Y. Miswati., A. Rohmah., E Andesyha., Romlah., R.S.D. Daulay., K. Safitria, Investigasi wabah penyakit pada itik di Jawa Tengah, Yogyakarta, dan Jawa Timur: Identifikasi sebuah clade baru virus avian influenza subtipe H5N1 di Indonesia. Bulletin Laboratorium Veteriner. Balai Besar Veteriner Wates Jogjakarta, 12(4) (2012) 2-9.

[15] E. Spackman, D.E. Swayne, D.I. Suarez, D.A. Senne, J.C. Pedersen, M.L. Killian, J. Pasick, K. Handel, S.P.S. Pillai, C.W. Lee, D. Stallknecht, Characterization of low-pathogenicity $\mathrm{H} 5 \mathrm{~N} 1$ avian influenza viruses from North America. J. Virol., 81(21) (2007) 11612-11619.

[16] A. Kovacova, G. Ruttkay-Nedecky, I.A. Haverlik, S Janecek. Sequence similarities and evolutionary relationships of influenza virus A hemaglutinins. Virus. Genes. 24(1) (2002) 57-63.

[17] WHO, Review of latest available evidence on risks to human health through potential transmission of avian influenza (H5N1) through water and sewage. 2008.

Online: who.int/iris/bitstream/10665/204275/1/WHO_SDE WSH_06.1_eng.pdf. (Accessed: December $25^{\text {th }}$ 2020). 